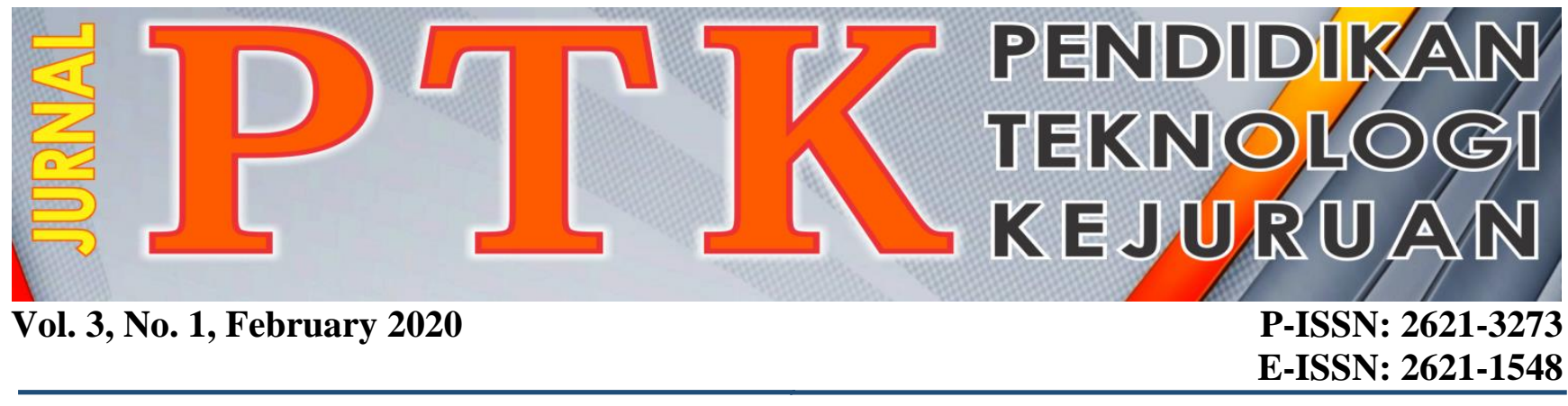

\title{
APPLICATION OF DATA MINING FOR ANALYSIS OF CONSUMER PURCHASE DATA ON SALES TRANSACTION DATA AT HALAL MART HNI HPAI DHARMASRAYA
}

\author{
Sri Kurnia Yuliarnis ${ }^{1}$, Yeka Hendriyani², Denny Kurniadi ${ }^{3}$, Giatman $^{4}$ \\ Universitas Negeri Padang \\ *Corresponding author, e-mail: srikurniayuliarnis@gmail.com
}

\begin{abstract}
The sales strategy determines the continuity of the business being run. The problems that occur are the sales archive data has not been analyzed in-depth, the information system has not been integrated with applications for sales data analysis, online media promotion has not been maximized, inadequate stock of goods, the layout of goods is not optimal, and the combination of the number of products is not optimal. This study aims to extract hidden information in the sales database using Data Mining. From the information generated, sales strategy recommendations are developed relating to promotions, inventory, catalogue design, item layout, and the combination of product quantities. The method used is the association rule with Apriori algorithm to find consumer purchase patterns through the resulting association. The importance of association can be identified by two benchmarks, namely support and confidence. The sales strategy analyzed includes product promotion, catalogue design, product layout, stock predictions, and product combinations for sale. Based on the research produced 7 strong rules which are the highest association rules which are then developed into a sales strategy recommendation.
\end{abstract}

Keywords: Association, Apriori, Sales Strategy

Copyright (C) 2020 JPTK. All rights reserved

\section{INTRODUCTION}

Proper marketing management will influence the long-term sustainability of the sales business. Likewise with external pressure that can affect sales strategies. However, some previous studies found that in sales data management sales archives are only used as a pile of data and have not been carried out in-depth analysis, the existing information system has not been integrated with applications that can analyze sales data, promotion with online media has not been maximized, less stock of goods according to request $[3,14]$, layout that is not optimal [1], and a combination of the number of products that are not yet optimal [4].

From these problems, the management can use data mining to extract hidden data. Data Mining is the process of finding useful new patterns in large databases [5]. Data mining is an integral part of the knowledge discovery database (KDD) which is the overall process of converting raw data into interesting data patterns which are the information needed by a user as knowledge as shown in figure 1 [7].

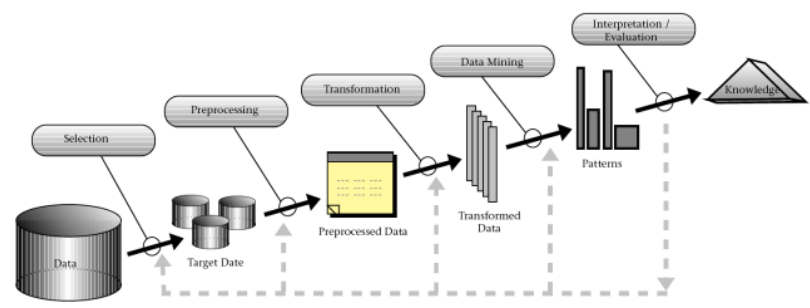

Figure 1. Knowledge Discovery Process in Database / KDD

There are several methods in data mining including association, clustering, prediction, estimation, description, and classification [9]. The task of association in data mining is to find attributes that appear at a time [7]. In the business world, it is more commonly called shopping basket analysis. Therefore, the method to be used is data mining association. Apriori has higher association rules than FP-Growth [6].

Therefore the hidden data can be used to find the tendency of goods purchased together in a 
transaction using Apriori algorithm [11]. After knowing the purchasing patterns of consumers the management can determine the next sales strategy related to promotion, catalogue design, product layout, product stock predictions, and the number of product combinations to be sold.

Apriori algorithm is an algorithm that searches for itemset frequencies by using the association rule technique, the selection of data mining techniques using association rules with Apriori algorithms shows better results in terms of truth, computation, and termination. $[10,12,15]$. To find the association rule of a data set, the first step that must be done is to look for the frequency of the itemset first [8]. A frequency itemset is a group of items that often appear together. The importance of an association can be known by two benchmarks, namely support and confidence. Support is the supporting value or percentage of a combination of items in the database, while confidence is the value of certainty, namely the strength of the relationship between items in the association rules [7].

\section{METHODOLOGY}

\section{Type of Research}

This type of research used is applied research or applied research carried out with regard to practical realities, applications, and development of knowledge produced by basic research in real life [13]. Applied research serves to find solutions to certain problems. The main purpose of applied research is problem-solving so that research results can be utilized for the benefit of humans either individually or in groups or for industrial or political purposes and not for scientific insight alone [16]. In other words, applied research is one type of research whose results can be directly applied to solve the problems encountered.

\section{Research Design}

The research design is a stage that will be carried out by the author to provide an overview and ease in conducting research.

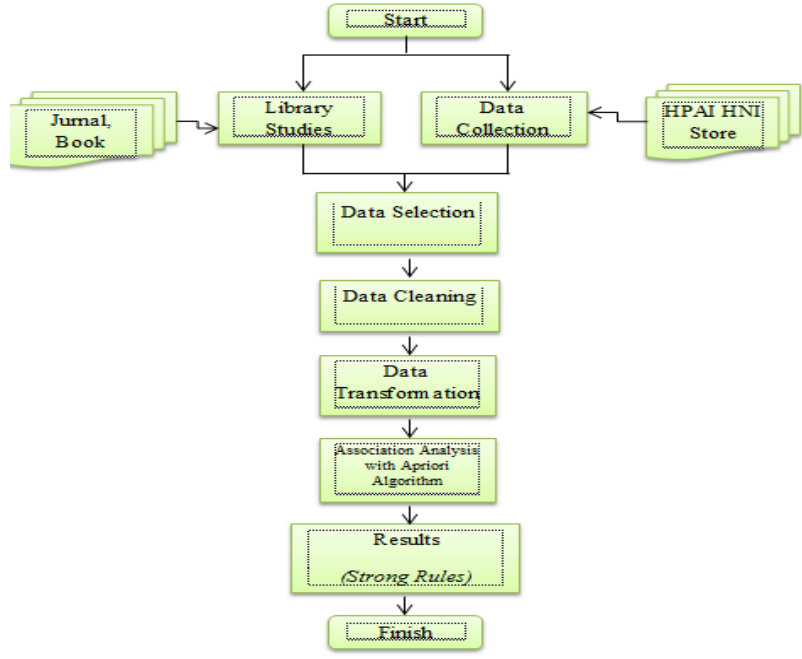

Figure 2. Research Design

\section{Population and Sample}

The population used in this study is the data of sales transactions of goods in the last 2 years (January 2015 - December 2016) obtained from Halal Mart HNI HPAI in Dharmasraya. The sample selection is done based on the Market Basket Analysis (MBA) method by looking for items that often appear in the sales data of goods at HNI HPAI Dharmasraya Halal Mart.

\section{Data Collection Techniques}

The techniques used by the author are:

2.4.1 Literature Study Done by collecting and studying literature relating to the concept of associating data mining with Apriori algorithms.

2.4.2 Literature sources in the form of textbooks, papers, journals, scientific papers, and supporting sites [2]. 2.4.2 Archive Data Collection Techniques By collecting data on sales transactions related to the attributes used in this study [2].

\section{Data Analysis Techniques}

Association analysis for extracting association rules is solving the problem into two main jobs, namely: (a) Frequent Itemset Generation The goal is to find all itemset that meets the threshold. The itemset is called a frequent item (itemset that appears frequently) (b) Rule Generation aims to extract rules with high confidence from the frequent itemset found in the previous step. There are two processes in the Apriori algorithm [7], as follows: 2.5.1 Join

In this process, each item is combined with other items until no more combinations are formed. 


\section{Prune}

In this process, the results of a combination of items will be trimmed using the minimum support specified by the user.

\section{Association Analysis with Apriori Algorithms}

The selection of attributes was chosen based on the Market Basket Analysis (MBA) method by looking for items that often appear in the transaction data of goods sales at HNI HPAI Halal Mart in Dharmasraya. Frequent items obtained from the results of the analysis will be used in this study.

To support the Apriori algorithm to produce the best results, the reference variables namely support and confidence must have a high correlation. Therefore, to map the correlation value, the Guilford table is used to classify the correlation coefficient [3]. The Guilford table is used to measure the correlation or closeness of relationships between variables [17]. The higher the correlation value between frequent itemset, the stronger the relationship. The correlation referred to in the Apriori algorithm is described based on the value of confidence.

Table 1. Guilford Table

\begin{tabular}{|ll|}
\hline ABSOLUTE VALUE OF $R$ & INTERPRETATION \\
\hline$<0.19$ & Slight; almost no relationship \\
$0.20-0.39$ & Low correlation; definite but small relationship \\
$0.40-0.69$ & Moderate correlation; substantial relationship \\
$0.70-0.89$ & High correlation; strong relationship \\
$0.90-1.00$ & Very high correlation; very dependable relationship \\
$\geq 0.30$ & Practically significant relationship \\
\hline
\end{tabular}

To support Apriori get the best results, the correlation formed must be strong so that the minimum confidence value is chosen at 0.7 or equal to $70 \%$ which according to Guilford's table, the range of 0.7 includes the high/strong correlation range. A minimum confidence value of 0.7 is considered as a number that includes a high correlation but also results in many required candidates. While the minimum support is chosen at 0.3 or equal to $30 \%$ to keep the algorithm from producing too many and not too few candidate items.

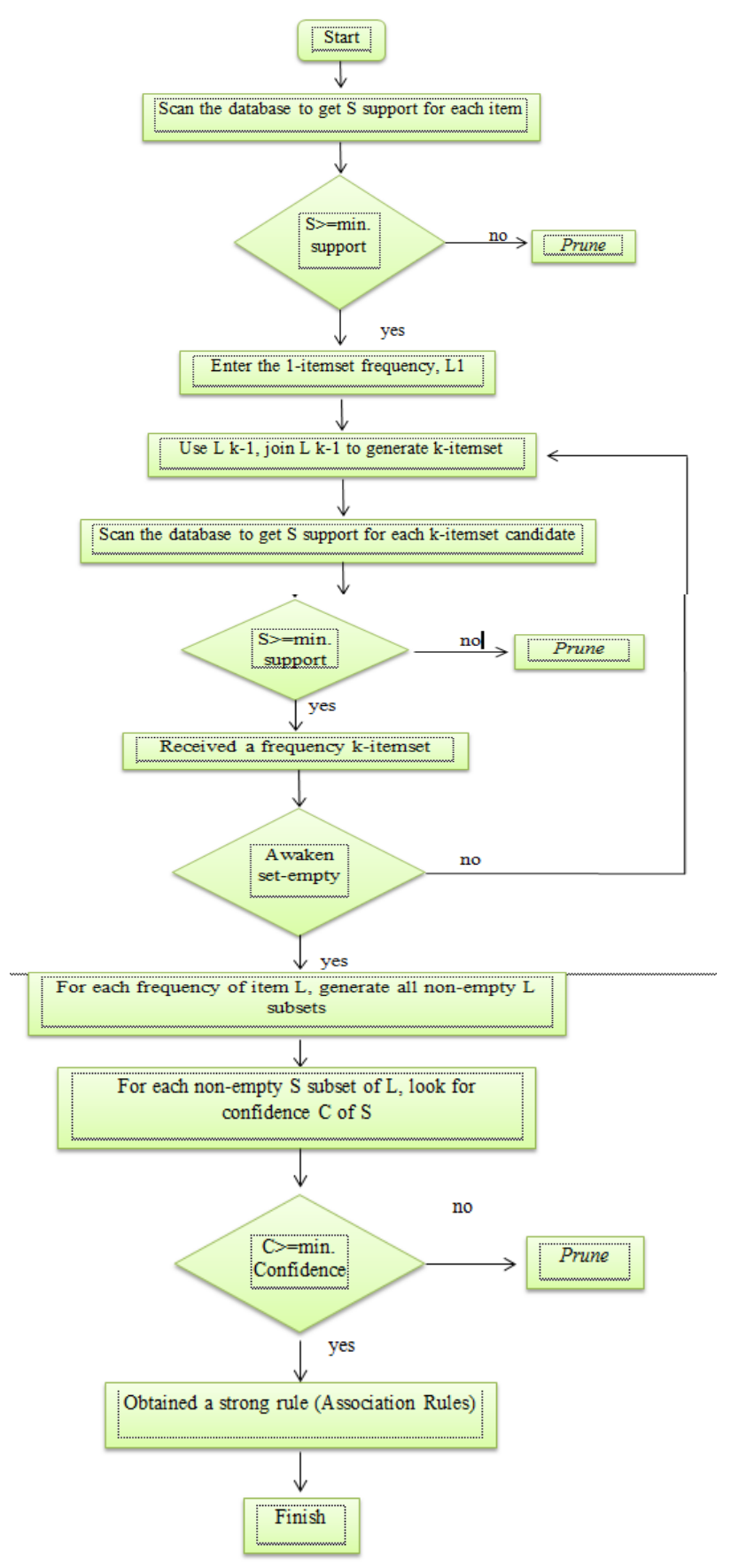

Figure 3. Apriori Algorithm Flowchart [7]

\section{RESULT AND DISCUSSION}

\section{Based on the Strong Rules Generated}

The strength of association rules is seen based on the value of support and confidence. To determine the association rules to be chosen, it must be sorted by Support x Confidence. The rules are taken as many as 7 rules that have the biggest result. 
Table 2. Strong Rules

\begin{tabular}{|c|c|c|c|c|c|}
\hline No & Association Rules & Amount & Support & Conf & Support x Confidence \\
\hline 1 & $\begin{array}{l}\text { Pasta Gigi Herbal Hpai New } \\
\rightarrow \text { Minyak Burung But But New (Wil 1\&2) }\end{array}$ & 24 & $100 \%$ & $100 \%$ & $100 \%$ \\
\hline 2 & $\begin{array}{l}\text { Minyak Burung But But New (Wil 1\&2) } \rightarrow \text { Pasta Gigi Herbal } \\
\text { Hpai New }\end{array}$ & 24 & $100 \%$ & $100 \%$ & $100 \%$ \\
\hline 3 & $\begin{array}{l}\text { Kopi Radix Sinergis Wil } 1 \\
\rightarrow \text { Pasta Gigi Herbal Hpai New }\end{array}$ & 22 & $91,7 \%$ & $100 \%$ & $91,7 \%$ \\
\hline 4 & $\begin{array}{l}\text { Kopi Radix Sinergis Wil } 1 \\
\rightarrow \text { Minyak Burung But But New (Wil 1\&2) }\end{array}$ & 22 & $91,7 \%$ & $100 \%$ & $91,7 \%$ \\
\hline 5 & $\begin{array}{l}\text { Pasta Gigi Herbal Hpai New, Kopi Radix Sinergis Wil } 1 \\
\rightarrow \text { Minyak Burung But But New (Wil 1\&2) }\end{array}$ & 22 & $91,7 \%$ & $100 \%$ & $91,7 \%$ \\
\hline 6 & $\begin{array}{l}\text { Minyak Burung But But New (Wil 1\&2), Kopi Radix Sinergis } \\
\text { Wil } 1 \\
\rightarrow \text { Pasta Gigi Herbal Hpai New }\end{array}$ & 22 & $91,7 \%$ & $100 \%$ & $91,7 \%$ \\
\hline 7 & $\begin{array}{l}\text { Kopi Radix Sinergis Wil } 1 \rightarrow \text { Pasta Gigi Herbal Hpai New, } \\
\text { Minyak Burung But But New (Wil 1\&2) }\end{array}$ & 22 & $91,7 \%$ & $100 \%$ & $91,7 \%$ \\
\hline
\end{tabular}

The first association rule produces a sales pattern if buying Herbal Hpai New Toothpaste then the tendency of consumers to buy But But New Bird Oil (Wil $1 \& 2$ ) with a support value of $100 \%$ (percentage of items combined in a sales transaction $=100 \%$ ) and $100 \%$ confidence value ( strong relationship of items in an Apriori $=100 \%$ ). With a strong rule, value is $100 \%$. This means if the consumer buys New Herbal Hpai Toothpaste then the possibility of the consumer buying But But New Bird Oil (Wil $1 \& 2$ ) is $100 \%$, meaning that it is always bought together.

The second association rule results in a sales pattern if buying But But New Bird Oil (Wil 1 \& 2) then the tendency of consumers to buy Herbal Hpai New Toothpaste with a value of $100 \%$ support (percentage of items combined in a sales transaction $=100 \%$ ) and $100 \%$ confidence value ( strong relationship of items in an Apriori $=100 \%$ ). With a strong rule, value is $100 \%$. This means if the consumer buys But But New Bird Oil (Wil $1 \& 2$ ) then the possibility of the consumer buying Herbal Hpai New Toothpaste is $100 \%$, meaning that it is always bought together.

The third association rule results in a sales pattern if buying Radix Synergic Wil 1 Coffee, the tendency of consumers to buy Herbal Hpai New Toothpaste with a support value of $91.7 \%$ (percentage of items combined in a sales transaction $=91.7 \%)$ and $100 \%$ confidence value ( strong relationship of items in an Apriori $=100 \%$ ).

With a strong rule, value is $91.7 \%$. The support value of $91.7 \%$ means that the Frequency of Radix Synergistic Wil 1 coffee is purchased together with New Hpai Herbal Toothpaste consumers in 24 transactions is $91.7 \%$ or equal to 22 times, while $100 \%$ confidence means the percentage of the amount of Herbal Hpai New Herbal Toothpaste on transactions containing Wilx Radix Synergistic Kopi
1 is $100 \%$. That is, in every purchase of Radix Synergic Wil 1 Coffee, consumers can be sure to buy New Hpai Herbal Toothpaste. But if consumers buy Hpai New Herbal Toothpaste, then the possibility of consumers also buying Radix Synergis Wil 1 Coffee is $91.7 \%$.

The fourth association rule produces a sales pattern if buying Wilx Radix Synergic Coffee, the tendency of consumers to buy But But New Bird Oil (Wil 1 \& 2) with a support value of $91.7 \%$ (percentage of items combined in a sales transaction $=91.7 \%$ ) and value $100 \%$ confidence (strong relationship items in an Apriori $=100 \%$ ). With a strong rule, value is $91.7 \%$.

The support value of $91.7 \%$ means that the Frequency of Radix Synergistic Wil 1 coffee is purchased together with But But New Bird Oil (Wil $1 \& 2$ ) in 24 transactions is $91.7 \%$ or equal to 22 times, while $100 \%$ confidence means the percentage of the amount of Bird Oil But But New (Wil $1 \& 2$ ) purchased on transactions containing Wil 1 Radix Synergistic Coffee is $100 \%$. That is, in every purchase of Radix Synergic Wil 1 Coffee, consumers can be sure to buy But But New Bird Oil (Wil $1 \& 2$ ). But if consumers buy But But New Bird Oil (Wil $1 \& 2$ ), then the possibility of consumers also buying Wil 1 Radix Synergistic Coffee is $91.7 \%$.

The fifth association rule generates a sales pattern if buying Hpai New Herbal Toothpaste and Radix Synergic Wil 1 Coffee, the tendency of consumers to buy But But New Bird Oil (Wil 1 \& 2) with a support value of $91.7 \%$ (percentage of item combination in a sales transaction $=91,7 \%$ ) and $100 \%$ confidence value (strong relationship of items in an Apriori $=100 \%)$. With a strong rule, value is $91.7 \%$.

The support value of $91.7 \%$ means that if consumers buy Hpai New Herbal Toothpaste and 
Radix Synergic Wil 1 Coffee, then the consumer also buys But But New Bird Oil (Wil $1 \& 2$ ) in 24 transactions is $91.7 \%$ or equal to 22 times, while $100 \%$ confidence means the percentage of the amount of But But New Bird Oil (Wil 1 \& 2) on transactions containing Herbal Hpai New Toothpaste and Radix Coffee.
Based on the strong rules found, it can be seen that the best-selling sales items for the past two years are Herbal Hpai New Toothpaste, But But New Bird Oil (Wil 1 \& 2), Wilx Synergistic Radix Coffee with a combination of items as shown in Table 3.

Table 3. Statistical Research Results

\begin{tabular}{|l|l|c|}
\hline \multicolumn{1}{|c|}{ No } & \multicolumn{1}{|c|}{ Combination of Goods } & Percentage \\
\hline 1 & $\begin{array}{l}\text { If consumers buy Pasta Gigi Herbal Hpai New, then the consumer also buys Minyak } \\
\text { Burung But But New (Wil 1\&2). }\end{array}$ & $100 \%$ \\
\hline 2 & $\begin{array}{l}\text { If consumers buy Minyak Burung But But New (Wil 1\&2), then the consumer also buys } \\
\text { Pasta Gigi Herbal Hpai New. }\end{array}$ & $\begin{array}{l}100 \% \\
\text { If consumers buy Kopi Radix Sinergis Wil 1, then the consumer also buys Pasta Gigi } \\
\text { Herbal Hpai New. }\end{array}$ \\
\hline 4 & $\begin{array}{l}\text { If consumers buy Kopi Radix Sinergis Wil 1, then the consumer also buys Minyak Burung } \\
\text { But But New (Wil 1\&2). }\end{array}$ & $91,7 \%$ \\
\hline 5 & $\begin{array}{l}\text { If consumers buy Pasta Gigi Herbal Hpai New dan Kopi Radix Sinergis Wil 1, then the } \\
\text { consumer also buys Minyak Burung But But New (Wil 1\&2). }\end{array}$ & $91,7 \%$ \\
\hline 6 & $\begin{array}{l}\text { If consumers buy Minyak Burung But But New (Wil 1\&2) dan Kopi Radix Sinergis Wil } \\
1, \text { then the consumer also buys Pasta Gigi Herbal Hpai New. }\end{array}$ & $91,7 \%$ \\
\hline 7 & $\begin{array}{l}\text { If consumers buy Kopi Radix Sinergis Wil 1, then the consumer also buys Pasta Gigi } \\
\text { Herbal Hpai New dan Minyak Burung But But New (Wil 1\&2). }\end{array}$ & $91,7 \%$ \\
\hline
\end{tabular}

From the statistical data above, it can be seen the combination of products that consumers often buy together. Available in Table 2.

3.2.1 Aspects of Promotion
The Author's recommendation to the management of Halal Mart HNI HPAI Dharmasraya related aspects of promotion is in Table 4.

\begin{tabular}{|c|c|c|}
\hline No & Aspect & Recommendation \\
\hline 1 & Direct Promotion & $\begin{array}{l}\text { Personal promotion will be more effective if done with a live demo of product } \\
\text { efficacy. Promoting agents are required to get to know the product well. }\end{array}$ \\
\hline 2 & Online media & $\begin{array}{l}\text { Maximize the use of social media to promote products, whether through Facebook, } \\
\text { WA, Twitter, Instagram, and other social media. }\end{array}$ \\
\hline 3 & Price & $\begin{array}{l}\text { The selling price is the first point that consumers see. Slight decrease in price but } \\
\text { not significantly reduce quality will help sales of products that sell less. }\end{array}$ \\
\hline 4 & Discount & $\begin{array}{l}\text { Giving special discounts to less-selling products such as buying } 2 \text { get } 1 \text { free will } \\
\text { make consumers interested in buying the product. }\end{array}$ \\
\hline 5 & Target Market & $\begin{array}{l}\text { Introducing products to consumers, of course, must adjust to the conditions of the } \\
\text { target market, for example, a good quality but expensive product will not suit rural } \\
\text { communities. Because rural communities tend to choose products with lower } \\
\text { prices. }\end{array}$ \\
\hline
\end{tabular}

Promotional aspects related to the price of goods are recommended to be given a price reduction but does not significantly reduce quality. Recommendations are aimed at products that are cut when calculating support and confidence. Products that are pruned during calculations are products that are rarely purchased by consumers. The recommended discount also aims to provide solutions for products that consumers rarely buy.

\subsubsection{Aspects of Catalog Design}

The author's recommendations to the management of Halal Mart HNI HPAI Dharmasraya regarding the aspects of catalogue design are in Table 5. 
Table 5. Catalog Design

\begin{tabular}{|c|l|l|}
\hline No & \multicolumn{1}{|c|}{ Aspect } & \multicolumn{1}{c|}{ Recommendations } \\
\hline 1 & Layout & $\begin{array}{l}\text { To balance best-selling products and products that are rarely purchased by consumers, the } \\
\text { layout of the design can be based on product characteristics, usability, and type of product. } \\
\text { Putting these items side by side will help consumers get to know other products. }\end{array}$ \\
\hline 2 & Price & $\begin{array}{l}\text { Write down the unit price of the product, so consumers can estimate how many products can be } \\
\text { purchased. }\end{array}$ \\
\hline 3 & Product Efficacy & $\begin{array}{l}\text { Include product efficacy. Products that have benefits in everyday life such as New Herbal Hpai } \\
\text { Toothpaste and But But New Bird Oil (Wil 1 \& 2), and Radix Synergis Wil 1 Coffee are placed } \\
\text { on the front page of the catalogue. }\end{array}$ \\
\hline 5 & $\begin{array}{l}\text { Product Name } \\
\text { and Image }\end{array}$ & $\begin{array}{l}\text { Provide a complete information link that potential customers can access on the first page of the } \\
\text { catalogue. }\end{array}$ \\
\hline 6 & $\begin{array}{l}\text { Make product names and images as attractive as possible so potential customers are interested } \\
\text { in reading the catalogue. }\end{array}$ \\
\hline
\end{tabular}

Manage product designs side by side between bestselling products and products that are rarely purchased by consumers but still pay attention to the grouping aims to introduce products that are not in demand to consumers. Products that are rarely purchased by consumers can be identified by trimming items when calculating minimum support and minimum confidence.

The minimum support set is $30 \%$ and the minimum confidence set is $70 \%$. In the calculation of support for one combination of items, 10 items are produced that meet the minimum support. In addition to the 10 items are trimmed and not included in the calculation of the next support.

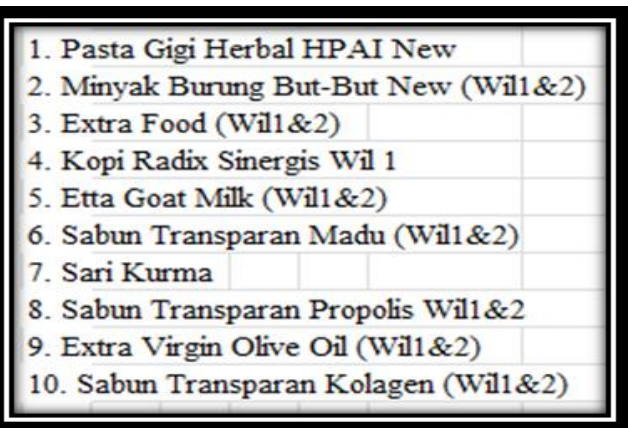

Figure 4. 10 Items that Meet Min Support 3.2.3

\subsubsection{Product Layout Aspects}

The author's recommendations to the management of Halal Mart HNI HPAI Dharmasraya regarding aspects of product layout are listed in Table 6.

Table 6. Layout

\begin{tabular}{|c|l|l|}
\hline No & \multicolumn{1}{|c|}{ Aspect } & \multicolumn{1}{c|}{ Recommendations } \\
\hline 1 & Shop Front & $\begin{array}{l}\text { a. As an initial attraction, place products that consumers often buy at the front of the } \\
\text { store. } \\
\text { b. It could be that the product is unsold because it is not touched by consumers, put the } \\
\text { product in a place that is easily accessible to consumers. } \\
\text { c. Products of the type of food or drink put in front of the store. }\end{array}$ \\
\hline 2 & $\begin{array}{l}\text { adjacent Products } \\
\text { consumers know the product. } \\
\text { b. Put the product with the same type as each group. For example Beauty day Cream } \\
\text { products, then place it with a group of cosmetic products. }\end{array}$ \\
\hline 3 & $\begin{array}{l}\text { Positions that are } \\
\text { easily explained and } \\
\text { seen by consumers }\end{array}$ & $\begin{array}{l}\text { Place the product in a place that is easily accessible to consumers, not too high or too low. } \\
\text { Put it also in a place that is easily seen by consumers. Especially for products that are } \\
\text { rarely purchased by consumers. }\end{array}$ \\
\hline 4 & $\begin{array}{l}\text { Back of the Store } \\
\text { The back can be used to put stock of spare goods which are more likely to be bought by } \\
\text { consumers. }\end{array}$ \\
\hline
\end{tabular}

Products that are rarely purchased by consumers may be untouched by consumers. Putting these products in a place that is easily accessible to consumers can be a solution for goods that consumers rarely buy.
Products that were originally rarely purchased can be juxtaposed with best-selling products so that consumers can see the product when they will take other bestselling products. 
Products that are rarely purchased can be identified through prior support and confidence calculations. The product will be trimmed in the calculation if it does not reach the minimum value.

\subsubsection{Prediction Aspects of Goods Stock}

The author's recommendations to the management of Halal Mart HNI HPAI Dharmasraya regarding aspects of stock prediction are listed in Table 7.

Table 7. Stock Prediction

\begin{tabular}{|c|l|l|}
\hline No & \multicolumn{1}{|c|}{ Aspect } & \multicolumn{1}{c|}{ Recommendations } \\
\hline 1 & Stok Prediction & $\begin{array}{l}\text { Using Association Analysis will make it easier to predict the stock that will be provided in the } \\
\text { future. }\end{array}$ \\
\hline 2 & $\begin{array}{l}\text { Large Product } \\
\text { Stock }\end{array}$ & $\begin{array}{l}\text { Best-selling products such as New Hpai Herbal Toothpaste and But But New Bird Oil (Wil 1 } \\
\text { \& 2), and Radix Synergic Wil 1 Coffee are provided in large quantities. }\end{array}$ \\
\hline 3 & Low Product Stock & Products that are rarely purchased by consumers can be provided in smaller quantities. \\
\hline
\end{tabular}

\subsubsection{Product Combination Aspects}

The author's recommendations to the

regarding aspects of product combinations are listed management of Halal Mart HNI HPAI Dharmasraya

Table 8. Combination of Goods

\begin{tabular}{|l|l|l|}
\hline No & \multicolumn{1}{|c|}{ Aspect } & \multicolumn{1}{c|}{ Recommendations } \\
\hline 1 & Discount & $\begin{array}{l}\text { The management can combine discounts in accordance with best-selling products } \\
\text { with products that are rarely purchased by consumers, can be given a special } \\
\text { discount package. It can be estimated what products will be given discounts } \\
\text { simultaneously. }\end{array}$ \\
\hline 2 & $\begin{array}{l}\text { Number of Products } \\
\text { Sold }\end{array}$ & $\begin{array}{l}\text { The combination of products sold in stores can adjust to the stock predictions that } \\
\text { have been discussed previously. Can be adjusted which products will be placed in } \\
\text { stores in large quantities and which products will be placed in stores in small } \\
\text { quantities. }\end{array}$ \\
\hline 3 & $\begin{array}{l}\text { Consumer Demand } \\
\text { products are the most in the list of consumer demand. Planning a combination of } \\
\text { goods can get a picture of consumer demand. For example, the three best-selling } \\
\text { products are provided in the amount of } 100 \text { items/day while the other products are } \\
\text { provided 60 items/day. }\end{array}$ \\
\hline
\end{tabular}

\section{Discussion}

Apriori algorithm in the association analysis process in the goods sales dataset is used to find several association rules that produce a pattern of interrelationships between each item purchased by consumers. In the Apriori Algorithm, there are two stages namely frequent item generation and rule generation.

The frequent item generation stage is looking for frequent itemset on each transaction. The Apriori Algorithm Principle states that if an itemset is a frequency, all subsets (parts) of that itemset must also be frequency and vice versa, if an itemset infrequent, all transactions containing the itemset and its superset are also infrequent itemset. The results of the analysis of the item sales dataset consisting of 43 items with a minimum support limit of $30 \%$ and $70 \%$ confidence produce a frequency itemset of 6 item combinations.

The second stage in the Apriori Algorithm is Rule Generation, which is to find several association rules using the frequency itemset that has been found. Association rules are calculated based on the value of confidence that meets the minimum confidence limit that has been set at $70 \%$.

Of the 18 highest association rules that have been sorted, we look for rules that are Strong Rule, those are the rules that have the highest support and confidence values. The analysis found 7 association rules that had the greatest support and confidence values and were included in the Strong Rules group. The information obtained from these studies is the 3 products most frequently purchased by consumers including New HPAI Herbal Toothpaste, But-But New Bird Oil (Wil1 \& 2), and Radix Synergistic Wil 1 Coffee.

This algorithm is based on the fact that Apriori uses prior knowledge of an itemset with frequent occurrences or often called frequent itemset. Apriori uses an iterative approach in which k-itemset is used to explore $(\mathrm{k}+1)$ - the next item [7].

\section{CONCLUSION}

Associated data mining methods with Apriori algorithms can be applied to research consisting of 43 product items and 24 different time purchases. 
The resulting strong rules are 7 combinations that can be utilized by the Halal Mart HNI HPAI Dharmasraya management to manage the sales strategy.

Information obtained from the research included 43 products studied that were found 3 products most frequently purchased by consumers, including New Herbal Hpai Toothpaste, But But New Bird Oil (Wil $1 \&$ 2) and Radix Coffee Synergistic Wil 1. All three products have the highest value of support and confidence. The highest strong rules that are produced have 100\% support and confidence, which means that these items are always purchased together during the specified period time.

The Apriori algorithm implementation in this study has been able to produce recommendations for the management of Halal Mart HNI HPAI Dharmasraya in conducting sales strategies related to the promotion of goods, catalogue design, the layout of goods, prediction of stock and combination of goods by following consumer purchasing patterns.

\section{REFERENCES}

[1] Agung, M. T., \& Nurhadiyono, B. (2015). Penerapan Data Mining pada Data Transaksi Penjualan untuk Mengatur Penempatan Barang Menggunakan Algoritma Apriori. Universitas.

[2] Creswell, J. W. (2014). A concise introduction to mixed methods research. SAGE publications.

[3] Erwin, E. (2009). Analisis Market Basket Dengan Algoritma Apriori dan FP-Growth. Jurnal Generic, 4(2).

[4] Fahmi, M., \& Sianturi, F. (2019). Analisa algoritma Apriori pada pemesanan konsumen di café the 1. Co coffe. Jurnal sains dan teknologi, 1(1), 52-57.

[5] Fajar Astuti. 2013. Data Mining. Yogyakarta: ANDI.

[6] Gunadi, G., \& Sensuse, D. I. (2016). Penerapan metode data mining market basket analysis terhadap data penjualan produk buku dengan menggunakan algoritma Apriori dan frequent pattern growth (fpgrowth): studi kasus percetakan pt. Gramedia. Telematika MKOM, 4(1), 118-132.

[7] Han, J \& Kamber, M. 2006. Data Mining Concepts and Technique. San Francisco: Morgan Kaufmann Publisher.
[8] Han, J., \& Kamber, M. (2012). J.(Computer scientist) Pei, Data mining: concepts and techniques.

[9] Kusrini dan Emha Taufiq Luthfi. 2009. Algoritma Data Mining. Yogyakarta: Andi.

[10] Mujiasih, S. (2011). Pemanfatan Data Mining Untuk Prakiraan Cuaca. Jurnal Meteorologi dan Geofisika, 12(2).

[11] Nafi'iyah, N., \& Wardhani, R. (2018). Analisa Pola Transaksi Penjualan Ikan di TPI Brondong Lamongan. Jurnal Spirit, 9(2).

[12] Nandagopal, S., Karthik, S., \& Arunachalam, V. P. (2010). Mining of meteorological data using modified Apriori algorithm. European Journal of Scientific Research, 47(2), 295308.

[13] Nawawi, H., \& Martini, M. (2005). Penelitian terapan. Gadjah Mada University Press.

[14] Nurchalifatun, F. (2015). Penerapan Metode Asosiasi Data Mining Menggunakan Algoritma Apriori Untuk Mengetahui Kombinasi Antar Itemset Pada Pondok KOPI. Fakultas Ilmu Komputer, Universitas Dian Nuswantoro.

[15] Santosa, B. 2007. Teknik Pemanfaatan Data untuk Keperluan Bisnis. Yogyakarta: Graha Ilmu Bisnis.

[16] Sukardi. 2003. Metode Penelitian dan Pendidikan Kompetensi dan Prakteknya. Jakarta: Bumi Aksara.

[17] Sugiyono. 2015. Metode Penelititan \& Pengembangan Research and Development. Bandung: Alfabet.

[18] R. Lapisa, I. Basri, M. Milana, and A. Arif, "Review Implementasi Teknologi Informasi dan Komunikasi dalam Kegiatan Pembelajaran: Studi Kasus SMK di Kota Padang Panjang", JPTK, vol. 2, no. 4, pp. 103109, Nov. 2019

[19] R. Nabawi, N. Jalinus, and S. Syahril, "MEWUJUDKAN TUJUAN PENDIRIAN AKADEMI KOMUNITAS MELALUI PENERAPAN MODEL PROJECT BASED LEARNING", JPTK, vol. 1, no. 2, pp. 51-58, May 2018.

[20] E. Saputra, W. Wakhinuddin, and F. Rizal, "Pengembangan Media Pembelajaran Elektronik Berbasis Masalah pada Mata Pelajaran Komputer dan Jaringan Dasar", JPTK, vol. 2, no. 2, pp. 39-44, May 2019. 